(Received July 15, 1983)

\title{
EFFECT OF HYDROGEN BOND FORMATION ON PHYSICAL AGING OF ETHYLENE-VINYL ALCOHOL COPOLYMERS WITH ANNEALING BELOW $T_{\mathrm{g}}$
}

\author{
By Hirohisa Yoshida, Hajime Kanbara ${ }^{* 1}$, Naoto Takemura ${ }^{* 2}$ \\ and Yasuii Kobayashi ${ }^{* 3}$ \\ (Department of Industrial Chemistry, Faculty of Technology, \\ Tokyo Metropolitan University, 2-1-1, Fukazawa, Setagaya-ku, \\ Tokyo 158 Japan)

\section{Synopsis}

The changes of the mechanical properties of poly(ethylene-co-vinyl alcohol) (EVA) with annealing below $T_{B}$ were studied. EVA samples obtained by quenching from the molten state, having $11-17 \%$ of crystallinity, were annealed at $\left(T_{\mathrm{g}}-10^{\circ} \mathrm{C}\right)$ for $4-160 \mathrm{hrs}$. From the stress-strain curves of the original and the annealed samples, yield strain $\left(\varepsilon_{y}\right)$, yield stress $\left(\sigma_{y}\right)$ and Young's modulus $(E)$ were obtained. The changes of $\varepsilon_{\mathrm{y}}$ with annealing depends on the VA content. $\sigma_{\mathrm{y}}$ and $E$ of all samples increased with the annealing. The changes of $E$ with annealing were discussed by assuming the first-order process. The higher the VA content, i.e., the richer the hydrogen bonding, the slower the rate of $E$ change with annealing. This result agreed with the fact that the enthalpy relaxation was testricted by the hydrogen bond formation.

\section{INTRODUCTION}

When an amorphous and/or semi-crystalline polymer is annealed at temperatures below its glass transition temperature $\left(T_{\mathrm{g}}\right)$, the morpholo$\mathrm{gy}^{1,2)}$. thermodynamic quantities ${ }^{3,4)}$ and mechanical properties ${ }^{5,6)}$ changes. These changes of physical properties with annealing below $T_{\mathrm{g}}$ were thermal reversible phenomena, and were known as "Physical Aging". Occurrence of physical aging in the glassy state is a manifestation of the slow process of the approach of the glass to thermodynamic equilibrium.

Extensive studies on the effect of physical aging on creep behavior of a number of polymers and other organic glasses were carried out by Struik ${ }^{5,7)}$. The effect of annealing on the physical properties of amorphous and semi-crystalline poly(ethylene terephthalate $)^{8,9)}$ and on the stress relaxation

*1 Present address: Shikoku Chemical Co. Ltd., Marugame, Kagawa-ken

*2 Present address: Terumo Co. Ltd., Hatagaya, Shibuya-ku, Tokyo

*3 Present address: Mejiro Gakuen Women's College, Nakaochiai, Shinjuku-ku, Tokyo behavior of polycarbonate, polystyrene and their polyblends ${ }^{10,11}$ ) were studied. Also, we reported the changes of mechanical properties and morphology of polystyrene with sub- $T_{\mathrm{g}}$ annealing ${ }^{12)}$.

In previous papers, we reported the effects of chemical structures ${ }^{13)}$, tacticity ${ }^{14}$ ) and hydrogen bonding $^{15)}$ on the rate of enthalpy relaxation of the glassy state of polymers with annealing below $T_{\mathrm{g}}$. These studies show that the enthalpy relaxation proceeded as a result of a cooperative segmental motion of a few consecutive repeating units. Also, the hydrogen bond formation delayed the rate of enthalpy relaxation.

In this study, the effect of hydrogen bonding on the changes of mechanical properties with annealing below $T_{\mathfrak{g}}$ was studied for the various content of ethylene-vinyl alcohol copolymers (EVA).

\section{EXPERIMENTAL}

\section{Sample}

Ethylene-vinyl acetate copolymers containing $22,28.5,43.2$ and 65.5 mole percent vinyl acetate were saponified under the presence of alkali (onehalf equivalent of $\mathrm{NaOH} /$ methanol solution) in 
toluene solution at $60^{\circ} \mathrm{C}$ for $10 \mathrm{hrs}$. After that, the partially saponified copolymers were re-saponified in methanol solution at $60^{\circ} \mathrm{C}$ for 6 hrs. After the removal of alkali, the obtained EVA samples were purified by the reprecipitation. The vinyl acetate content was less than 0.1 mole percent in every EVA. From elemental analysis, the vinyl alcohol contents of the obtained copolymers were $25,30,42$ and 68 mole percent.

EVA was pressed at $150^{\circ} \mathrm{C}(25-\mathrm{EVA}), 160^{\circ} \mathrm{C}$ (30-EVA), $180^{\circ} \mathrm{C}$ (42-EVA) and $200^{\circ} \mathrm{C}$ (68-EVA) in a hot press and quenched in ice water. The thickness of films were about $0.3 \mathrm{~mm}$. The specimens for tensile test (width $5 \mathrm{~mm} \times$ length $100 \mathrm{~mm}$ ) were cut out from the pressed film and dried for a week over phosphorus pentoxide in vacuo. After drying, the specimens were kept at temperature 10 degrees above the corresponding glass transition temperatures $\left(T_{\mathrm{g}}\right)$ for 5 minutes in order to eliminate the previous thermal history. After that, the samples were quenched to room temperature. The specimens thus prepared were used as the "original" sample.

\section{Annealing}

Samples were sealed in a glass tube which were filled with dry nitrogen gas, and were annealed at $33^{\circ} \mathrm{C}$ (25-EVA), $40^{\circ} \mathrm{C}$ (30-EVA), $48^{\circ} \mathrm{C}$ (42-EVA) and $55^{\circ} \mathrm{C}(68-\mathrm{EVA})$. Before annealing, the previous thermal history of samples were cancelled by the same way described above. After that, the samples were quenched to the annealing temperature, and were annealed. Immediately after annealing, the samples were used for the tensile test.

\section{Apparatus}

The thermal analysis of samples were carried out by use of a DuPont differential scanning calorimeter DSC 990 at the heating rate of $10^{\circ} \mathrm{C} / \mathrm{min}$. Before measuring $T_{\mathrm{g}}$, samples were heated to temperature 10 degrees above the corresponding $T_{\mathrm{g}}$ 's in order to eliminate the previous thermal history, and quenched to $-30^{\circ} \mathrm{C}$. $T_{\mathrm{g}}$ was estimated from the intersection between the initial base line and the sloping portion of the line as the base line shifts during the transition.

The tensile test was carried out by use of a conventional tensile tester, which covered the rate of deformation from $1.7 \times 10^{-4}$ to $2.8 \times 10^{-2}$ $\mathrm{m} / \mathrm{sec}$. The numbers of measurements tested per each specimen were eleven. The stress-strain curves gave Young's modulus $(E)$, tensile stress at yield $\left(\sigma_{y}\right)$, and extention to yield $\left(\varepsilon_{y}\right)$. The tensile test were carried out at $23 \pm 1^{\circ} \mathrm{C}$. The substantial dimensions for the test were $5 \mathrm{~mm}$ in wide and $60 \mathrm{~mm}$ in length.

X-ray diffractograms of the samples were obtained with a Rigaku Denki Model RU-3 diffractometor provided with a proportional counter.

\section{RESULTS AND DISCUSSION}

The DSC curves of EVA samples were shown in Fig. 1. Not only the glass transition but also the small melting peak were observed for every sample. Generally, the glass transition temperature $\left(T_{\mathrm{g}}\right)$ of polymers depends on the annealing ${ }^{4,9}$ ). As EVA have the low $T_{\mathrm{g}} \mathrm{s}$ near room temperature, the aging occurred and $T_{\mathrm{g}}$ changed while samples were handled at room temperature. For amorphous polymers such as polystyrene and/or poly(methyl methacrylate), the previous thermal history can be eliminated by heating to temperature $30^{\circ} \mathrm{C}$ above $T_{\mathrm{g}}$. After such a treatment, the amorphous polymer shows $T_{\mathrm{g}}$ which is independent on the thermal history. For EVA, however, the crystallization occurred in the temperature range between $T_{\mathrm{g}}+20^{\circ} \mathrm{C}$ and the melting temperature $\left(T_{\mathrm{m}}\right)$. In this study, EVA samples were held at $T_{\mathrm{g}}+10^{\circ} \mathrm{C}$ for 5 minutes and quenched to room temperature, in order to eliminate the previous thermal history without any crystallization. The increase of crystallinity with this treatment was negligible for every sample.

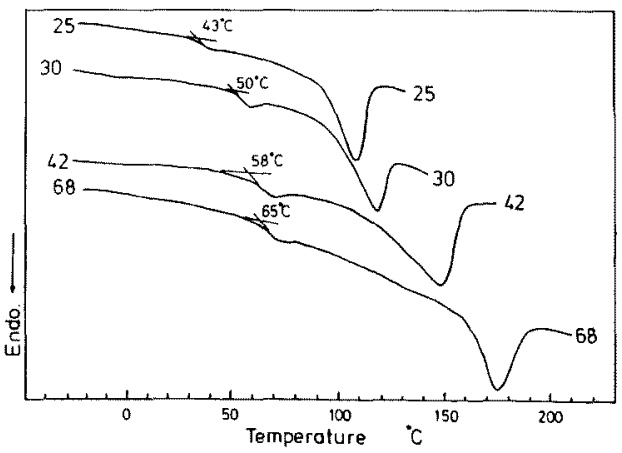

Fig. 1 DSC curves of ethylene-vinyl alcohol copolymers (EVA). Numbers in figure show vinyl alcohol content (mol\%). Heating rate is $10^{\circ} \mathrm{C} / \mathrm{min}$. 
$T_{\mathrm{g}}$ and $T_{\mathrm{m}}$ of the original samples were listed in Table 1, and the values show good agreements with the previous papers ${ }^{16,17)}$. According to Matsumoto et al. ${ }^{16)}, T_{\mathrm{g}}$ of EVA increased suddenly above 15 mole\% of vinyl alcohol content because of the increase of hydrogen bond formation. As EVA is the typical random copolymer ${ }^{17)}$, the hydrogen bond should distribute randomly. Also, the annealing temperature $\left(T_{\mathrm{a}}\right)$ was shown in Table 1.

Table 1 Thermal analysis results of samples.

\begin{tabular}{ccccc}
\hline Sample & $\begin{array}{c}\text { VA content } \\
(\mathrm{mol} \%)\end{array}$ & $\begin{array}{c}T_{\mathrm{g}}{ }^{* 1} \\
\left({ }^{\circ} \mathrm{C}\right)\end{array}$ & $\begin{array}{c}T_{\mathrm{m}}{ }^{* 2} \\
\left({ }^{\circ} \mathrm{C}\right)\end{array}$ & $\begin{array}{c}T_{\mathrm{a}}{ }^{* 3} \\
\left({ }^{\circ} \mathrm{C}\right)\end{array}$ \\
\hline 25-EVA & 25 & 43 & 109 & 33 \\
30-EVA & 30 & 50 & 118 & 40 \\
42-EVA & 42 & 58 & 146 & 48 \\
68-EVA & 68 & 65 & 178 & 55 \\
\hline
\end{tabular}

*1 Glass transition temperature obtained at $10^{\circ} \mathrm{C} / \mathrm{min}$.

${ }^{* 2}$ Melting temperature obtained at $10^{\circ} \mathrm{C} / \mathrm{min}$.

- ${ }^{3}$ Annealing temperature $\left(T_{\mathrm{g}}-10^{\circ} \mathrm{C}\right)$

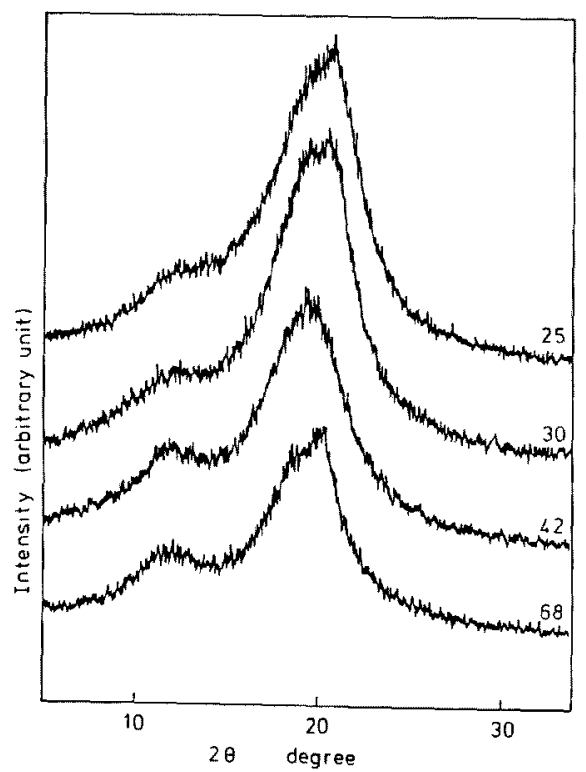

Fig. 2 X-ray diffractograms of original EVA. Direction of incident X-ray beam is perpendicular to film surfaces. Numbers in figure show vinyl alcohol content (mol\%).
The X-ray diffractograms of the samples were shown in Fig. 2. The direction of the incident $X$-ray beam was perpendicular to the film surfaces. Every sample show low crystallinity. Usually, it is difficult to obtain the exact value of crystallinity. In this study, the degree of crystallinity was estimated by the assumption of additivity of the heat of fusion based on mole fraction of copolymers. From the heat of fusion, the degree of crystallinity of every sample were about $11-17 \%$ by the use of the heat of fusion for polyethylene

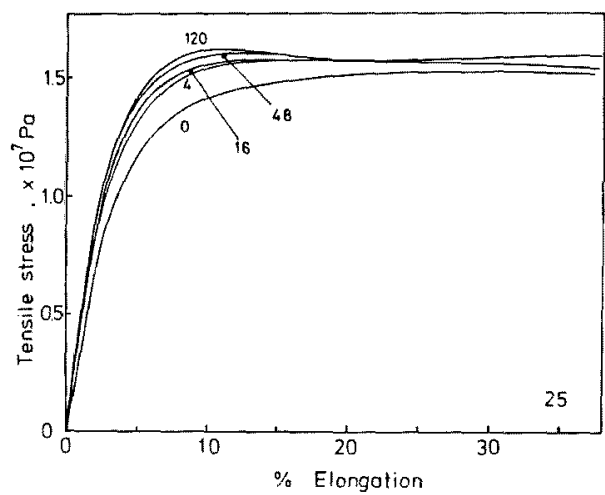

Fig. 3 Stress-strain curves of original and annealed 25-EVA ( $25 \mathrm{~mol} \%$ vinyl alcohol). Annealing temperature is $33^{\circ} \mathrm{C}$ and numbers in figure show annealing time (hrs). Samples are deformed at $23^{\circ} \mathrm{C}$ at rate of $1.7 \times 10^{-4}$ $\mathrm{m} / \mathrm{sec}$.

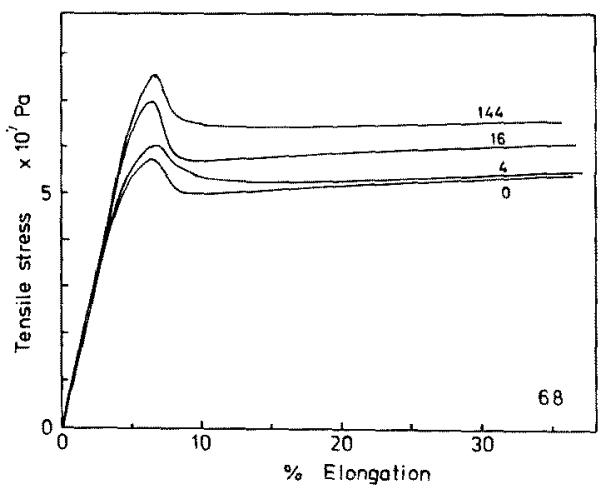

Fig. 4 Stress-strain curves of original and annealed 68-EVA (68 mol\% vinyl alcohol). Annealing temperature is $55^{\circ} \mathrm{C}$ and numbers in figure show annealing time (hrs). Samples are deformed at $23^{\circ} \mathrm{C}$ at rate of $1.7 \times 10^{-4}$ $\mathrm{m} / \mathrm{sec}$. 
$(7.87 \mathrm{~kJ} / \mathrm{mol})$ and poly(vinyl alcohol) $(6.87 \mathrm{~kJ} /$ mol $)^{18)}$. The X-ray diffraction did not change with annealing below $T_{\mathrm{g}}$ for every sample. With the increase of vinyl alcohol contents, the degree of crystallinity increased slightly.

The typical changes of stress-strain curves with annealing below $T_{\mathrm{g}}$ were shown in Fig. 3 (25-EVA) and Fig. 4 (68-EVA). 25-EVA and 68-EVA were annealed at $33^{\circ} \mathrm{C}$ and $55^{\circ} \mathrm{C}$, respectively. Numbers in the figures show the annealing time (hr). The rate of deformation was $1.7 \times 10^{-4} \mathrm{~m} / \mathrm{sec}$. The higher strength of 68-EVA should come from the hydrogen bonding.

For the stress-strain curves of 25-EVA, the yield point was not observed clearly. However, necking appears in both samples. For 25-EVA, the yield stress and Young's modulus, which was obtained from the initial slope of stress-strain curve, increased with annealing. On the other hand, the yield stress increased and the yield behavior become clear with the annealing on the stress-strain

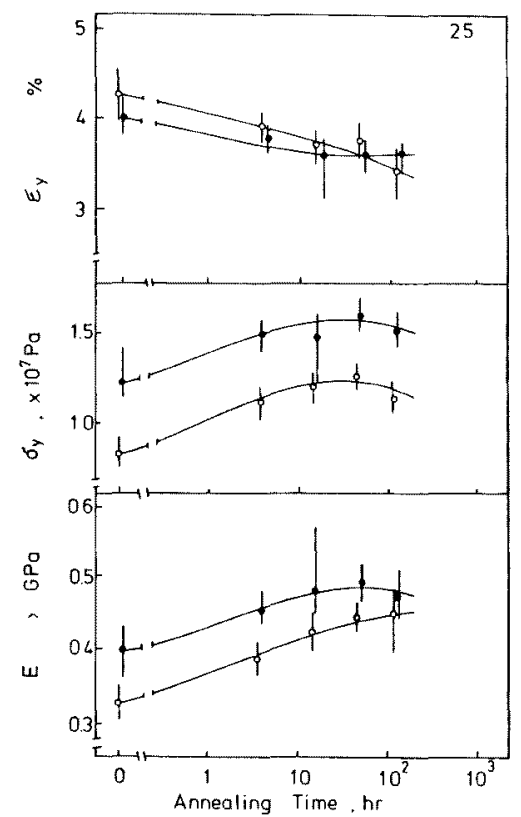

Fig. 5 Dependences of yield strain $\left(\varepsilon_{y}\right)$, yield stress $\left(\sigma_{y}\right)$ and Young's modulus $(E)$ on annealing time for 25-EVA. Annealing temperature is $33^{\circ} \mathrm{C}$. Samples are deformed at $23^{\circ} \mathrm{C}$ at rate of $1.7 \times 10^{-4}(0)$ and $1.7 \times 10^{-3}(0) \mathrm{m} / \mathrm{sec}$. curve of 68-EVA. However, Young's modulus of 68-EVA scarcely increased with annealing. The stress-strain curves of 30-EVA and 42-EVA are similar to those of 25-EVA and 68-EVA, respectively.

The changes of mechanical quantities with sub- $T_{\mathrm{g}}$ annealing were shown in Fig. 5 (25-EVA), Fig. 6 (30-EVA), Fig. 7 (42-EVA) and Fig. 8 (68EVA). In Figs. 5-8, open and close circles show the values at the deformation rate of $1.7 \times 10^{-4}$ and $1.7 \times 10^{-3} \mathrm{~m} / \mathrm{sec}$, respectively.

As the yield point of 25-EVA was not clear as shown in Fig. 3, it was difficult to determine the yield point. We determined the yield point of 25-EVA as the point where the stress-strain curve deviated from the initial linear slope. For 25-EVA, $\varepsilon_{y}$ decreased and $\sigma_{y}$ and $E$ increased with the annealing as shown in Fig. 5. According to Petrie ${ }^{19)}$, the ductile properties of amorphous poly(ethylene terephtalate) and atactic polystyrene changed to the brittle ones with annealing below

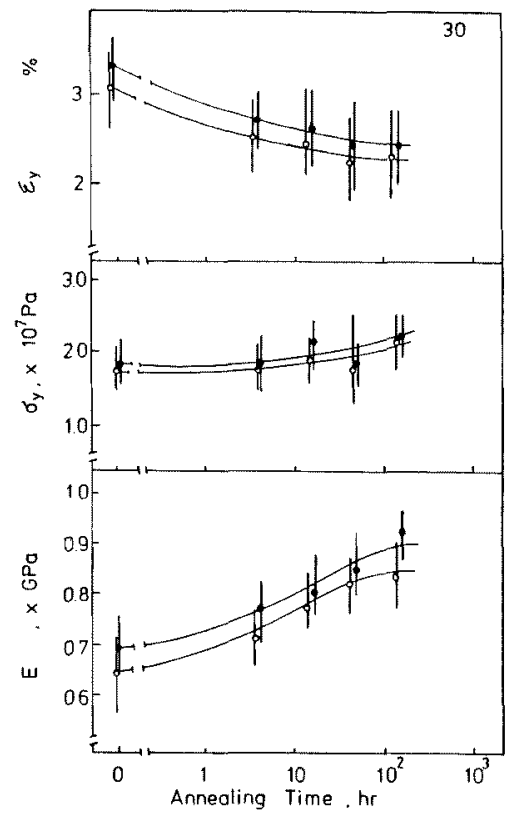

Fig. 6 Dependences of yield strain $\left(\epsilon_{y}\right)$, yield stress $\left(\sigma_{y}\right)$ and Young's modulus $(E)$ on annealing time for 30-EVA. Annealing temperature is $40^{\circ} \mathrm{C}$. Samples are deformed at $23^{\circ} \mathrm{C}$ at rate of $1.7 \times 10^{-4}(O)$ and $1.7 \times 10^{-3}(0) \mathrm{m} / \mathrm{sec}$. 


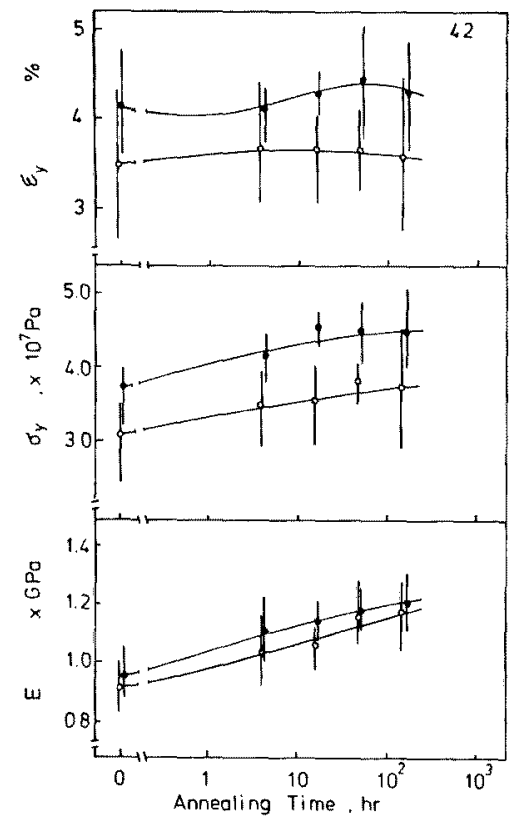

Fig. 7 Dependences of yield strain $\left(\varepsilon_{y}\right)$, yield stress $\left(\sigma_{y}\right)$ and Young's modulus $(E)$ on annealing time for 42-EVA. Annealing temperature is $48^{\circ} \mathrm{C}$. Samples are deformed at $23^{\circ} \mathrm{C}$ at rate of $1.7 \times 10^{-4}(0)$ and $1.7 \times 10^{-3}(0) \mathrm{m} / \mathrm{sec}$.

$T_{\mathrm{g}}$

The stress-strain curve of the original 30-EVA was similar to that of 25-EVA, and the yield point was not clear. For the annealed sample of 30-EVA, however, the yield point appeared. With an increase of annealing time, $\varepsilon_{y}$ decreased and $\sigma_{y}$ and $E$ increased slightly as shown in Fig. 6. For 42-EVA in Fig. 7, the yield point appeared on the stress-strain curve, and $\varepsilon_{\mathrm{y}}$ scarcely changed with annealing but $\sigma_{y}$ and $E$ increased slightly. For 68-EVA, $\varepsilon_{\mathrm{y}}, \sigma_{\mathrm{y}}$ and $E$ increased with annealing as shown in Fig. 8.

As shown in Figs. 5-8, the changes of $\varepsilon_{y}$ with annealing depend on the VA content. $\varepsilon_{\mathbf{y}}$ of 25-EVA decreased more than that of 30-EVA with sub- $T_{\mathrm{B}}$ annealing. On the other hand, $\varepsilon_{\mathrm{y}}$ of 42 EVA scarcely changed, and $\varepsilon_{y}$ of 68-EVA increased slightly with annealing. This phenomena may come from the difference of yield behavior among samples. As shown in Fig. 3 and 4, the yield point was scarcely observed on the stress-strain curves

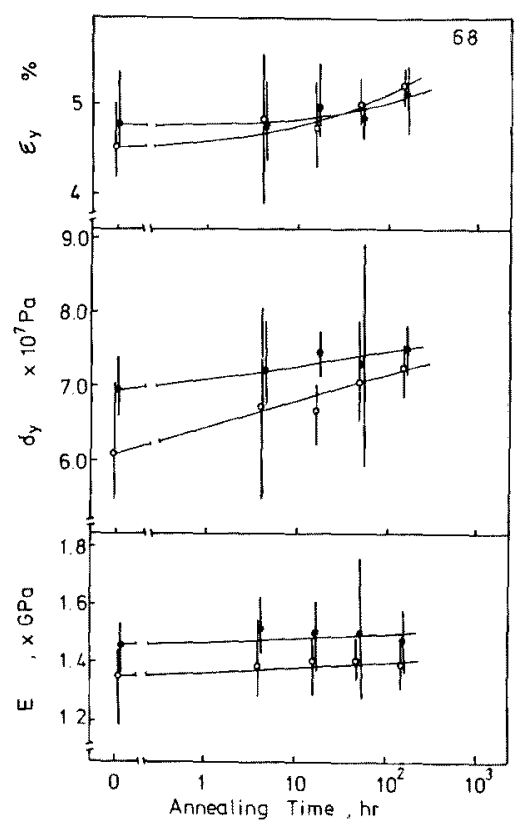

Fig. 8 Dependences of yield strain $\left(\varepsilon_{y}\right)$, yield stress $\left(\sigma_{y}\right)$ and Young's modulus $(E)$ on annealing time for 68-EVA. Annealing temperature is $55^{\circ} \mathrm{C}$. Samples are deformed at $23^{\circ} \mathrm{C}$ at rate of $1.7 \times 10^{-4}$ (O) and $1.7 \times 10^{-3}(\bullet) \mathrm{m} / \mathrm{sec}$.

of 25 and 30-EVA. On the other hand, the stressstrain curves of 42 and 68-EVA showed the yield point clearly. Despite all samples are deformed at temperature below $T_{\mathrm{g}}$, there may be difference of yield mechanism among samples.

According to Petrie ${ }^{19}$, the changes of modulus are parallel to the extent of enthalpy relaxation that occurred during the annealing as a result of the nonequilibrium nature of the glassy state, i.e., the modulus increased with time and approached a limiting value that increased with decreasing temperature. In a previous paper ${ }^{15)}$, Young's modulus of atactic polystyrene also increased with annealing. Therefore, Young's modulus $E$ calculated from the initial slope of the stress-strain curve will reflect the annealing effect. From Figs. 5-7, $E$ increased with annealing and approached a limiting value. However, $E$ of 68-EVA increases slightly within the experimental time scale, and it might further increase.

In order to analyze the physical aging process 
kinetically, the changes of $E$ with annealing were noted. The changes of $E$ was assumed as a firstorder reaction, just as in the cases of thermosseting plastics ${ }^{20)}$ and the hydrogen bond formation ${ }^{21}$ )

Generally, the kinetic process can be described as;

$$
\frac{\mathrm{d} x}{\mathrm{~d} t}=k(a-x)^{n}
$$

where, $a, x$ and $n$ are the initial concentration, the quantity reacted at time $t$ and the reaction order, respectively. When the initial condition is that $x=0$ at $t=0$, the integrated equation gives the first-order process;

$$
\ln \left(\frac{a}{a-x}\right)=k t
$$

where, $k$ is the rate constant. If there is a linear relation between $x$ and physical property $(M)$ changes, we obtain equations as follows;

$$
\begin{aligned}
a-x & =M_{\infty}-M_{t} \\
a & =M_{\infty}-M_{0} \\
x & =M_{t}-M_{0}
\end{aligned}
$$

When applying the external forces to the materials, the rearrangement of molecules will occur to relax the stress. The increase in Young's modulus is due to the increased time required for molecular rearrangements. As free volume and molecular mobility of the glasses decrease with annealing below $T_{\mathrm{g}}{ }^{5,9)}$, molecular responses against the external forces become slower. Therefore, $a$ and $x$ are assumed the molecular mobility at time 0 and $t$, respectively, and $M$ is assumed Young's modulus. Although the values of $E$ have not always saturated within the experimental time, $M_{\infty}$ and $M_{0}$ are regarded the values of $E$ for the samples annealed for $160 \mathrm{hrs}$ and the original one, respectively, When equations (3)-(5) are substituted in equation (2), we obtained equation (6) for $E$ change with annealing.

$$
\ln \left(\frac{E_{160}-E_{0}}{E_{160}-E_{t}}\right)=k t
$$

Thus, when $\ln \left[\left(E_{160}-E_{0}\right) /\left(E_{160}-E_{t}\right)\right]$ was plotted against the annealing time, a linear relation was obtained for the initial stage as shown in Fig. 9. For 25-EVA and 30-EVA, the plot for a long time

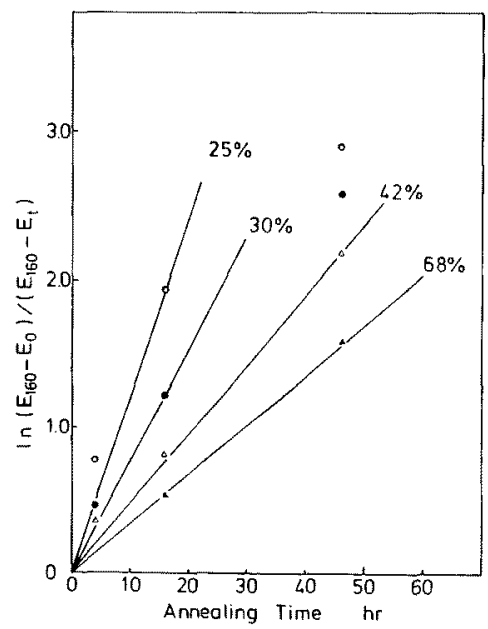

Fig. 9 Plots of $\ln \left(E_{160}-E_{0}\right) /\left(E_{160}-E_{t}\right)$ vs annealing time. Numbers in figure show vinyl alcohol content (mol\%).

annealing deviated from the linear relation. It was thought that the initial stage could not be detected within the experimental time scale, since the rate of $E$ changes of these samples with annealing was too fast. Such a change of $E$ with sub- $T_{\mathrm{g}}$ annealing may be not necessarily the same for the cases of thermossetting plastics ${ }^{20}$ ) and the hydrogen bond formation $^{21}$ which could be assumed as a firstorder process. In previous papers ${ }^{22,23)}$ the relaxation time increased with annealing time in the enthalpy relaxation process with annealing. If the changes of $E$ shown in Fig. 9 is consistent with the changes of thermodynamic quantities such as enthalpy and volume with annealing, the deviation of 25-EVA and 30-EVA in the long annealing time may be explained by use of the concept of the time dependence of the relaxation time in the enthalpy relaxation process. Also, the rate of molecular mobility changes would vary with the free volume fraction due to the feed back effect as indicated by Struik ${ }^{5}$ )

From the slope of each straight line, the values for $k$ in Fig. 9 were estimated. It is suggested that the rate of $E$ change with annealing becomes slower with the increase of VA content, i.e., the increase of the number of hydrogen bonding. This result agreed with the fact that the enthalpy relaxation process was restricted by the hydrogen bond formation ${ }^{14)}$. Therefore, the changes of $E$ 
with annealing may be correlated to the relaxation of thermodynamic quantities, such as free volume and enthalpy.

\section{REFERENCES}

1) G.S.Y. Yeh and P.H. Geil; J. Macromol. Sci.Phys., B1, 235 (1967)

2) W. Frank, H. Godder and H. A. Stuart; Polymer Letter, 5, 711 (1967)

3) A. J. Kovacs; J. Polym. Sci., 30, 131 (1958)

4) H. Suga and S. Seki; J. Non-Crystalline Solids, 16, 171 (1974)

5) L.C.E. Struik; "Physical Aging in Amorphous Polymers and Other Materials", Elsevier, Amsterdam (1978)

6) K. Neki and P. H. Geil; J. Macromol. Sci-Phys., B8, 295 (1973)

7) L.C. E. Struik; Polym. Eng. Sci., 17, 165 (1977)

8) R. M. Mininni, R. S. Moore, J. R. Flick and S. E. B. Petrie; J. Macromol. Sci.Phys., B8, 343 (1973)

9) M. R. Tant and G. L. Wilkes; J. Appl. Polym. Sci. 26, 2813 (1981)

10) S. Matsuoka, C. J. Aloisio and H. E. Bair; J. Appl. Phys., 44, 4265 (1973)
11) H. Matsuoka and H. E. Bair; ibid, 48, 4058 (1977)

12) H. Yoshida and Y. Kobayashi; Polymer, in press (1983)

13) H. Yoshida and Y. Kobayashi; J. Macromol. Sci.-Phys., B21, 565 (1982)

14) H. Yoshida, K. Nakamura and Y. Kobayashi; Polymer J., 14, 855 (1982)

15) H. Yoshida and Y. Kobayashi; ibid, 14, 925 (1982)

16) T. Matsumoto and K. Nakamae; Koubunsi Kagaku, 28, 610 (1971)

17) H. Yoshida and Y. Kobayashi; Sen-i Gakkaishi, 33, T-479 (1977)

18) J. Brandrup and E. H. Immergut, "Polymer Handbook", III-5, J. Willy \& Sons, New York

19) S. E. B. Petrie; J. Macromol. Sci.Phys., B12, 225 (1976)

20) D. H. Kaelble and E. H. Cirlin; J. Polym. Sci., C35, 79 (1971)

21) S. Yano, H. Hatakeyama and T. Hatakeyama; J. Appl. Polym. Sci., 20, 3221 (1976)

22) H. Yoshida and Y. Kobayashi; Sen-i Gakkaishi, 37, T-458 (1981)

23) H. Yoshida and Y. Kobayashi; ibid, 39, T-146 (1983)

ガラス転移温度以下の熱処理によるエチレンー

ビニルアルコール共重合体の機械的性質の変化

過程におよぼす水素結合の効果

東京都立大学工学部 吉日博久, 神原 筆,

竹村直人，小林端二

ビニルアルコール成尔のモル竹率が 25，30，42，68\% のエチレンービニルアルコール共重合体（EVA）を用い て， $T_{\mathrm{g}}$ 以下の温度での熱好理が試料の力学的性質飞拀 上ばす影響在検討しだ。溶融状態加ら急命によって得ら れた結昆化度 11 17\%のEVA試料を，各々の $T_{\mathrm{g}}$ より $10^{\circ} \mathrm{C}$ 低い温度で4 - 160 時間熱処理した。未熱処理試料 之熱処理試料の引つ張り試験加ら得られた応力一霆曲線 より，降伏伸び $\left(\varepsilon_{y}\right)$ ，降伏応力 $\left(\sigma_{y}\right)$ ，ヤング率 $(E)$ を 計算した。 $\varepsilon_{y}$ の熱起理による変化はVA組成によって異
なる挙動を示した。 $\sigma_{\mathrm{y}}$ とEはすへての試料について熱 処理時問によむなって增加した。 $T_{\mathrm{g}}$ 以下の熱処理によ るEの增加過程を，一次の動力学的過程として解析した。 熱処理に上るEの変化速度はVA組成が高くなる程, す なわち水素結合の数が多くなる程, 遅くなる。とれは $T_{\mathrm{g}}$ 以下の熱姏理によってェンタルピーや体皘などの熱力学 量の楥和過程が水素結合によって阻害される結果亡良い 一致を示した。 